\title{
Perancangan Tahapan Pengembangan Rantai Pasok Industri Furnitur Menuju Industri 4.0
}

\author{
Janah Darul Husni Ila Sabili dan Janti Gunawan \\ Departemen Manajemen Bisnis, Institut Teknologi Sepuluh Nopember (ITS) \\ e-mail: janti_g@mb.its.ac.id
}

\begin{abstract}
Abstrak-Perkembangan industri telah mencapai tingkat keempat yang disebut industri 4.0 dengan ditandainya integrasi teknologi dari Cyber-Physical-System di manufaktur dan proses logistik, serta penggunaan Internet of Thing (IoT) dan jasa di proses industrial. Industri 4.0 ini memberikan dampak dan kemudahaan implementasi sedang kepada industri furnitur. Industri furnitur merupakan salah satu komoditas yang dapat mendukung perekonomian dengan tingkat ekspor dengan penentu daya saing yaitu bahan baku, proses produksi, desain dan inovasi, serta pemasaran. Disisi lain dalam skala yang lebih luas industri 4.0 akan membawa perubahan peradaban pada serangkaian rantai nilai. Oleh sebab itu pada penelitian ini memetakan rantai nilai dari rantai pasok industri furnitur Indonesia agar dapat bersaing di era industri 4.0. Metode rantai nilai digunakan untuk memetakan rantai nilai dari industri furnitur dan melihat tingkat penggunaan teknologi dan teknologi informasinya. Dari hasil didapatkan perlunya pengembangan pada industri furnitur yang masih tergolong industri 2.0, pengembangan dilakukan pada aktivitas operasional serta aktivitas pemasaran dan penjualan pada industri mebel yang memiliki tingkat penggunaan teknologi dan teknologi informasi yang masih sedang dibandingkan dengan industri 4.0. Pengembangan startegi untuk kedua aktivitas tersebut menggunakan metode delphi menghasilkan 24 usulan strategi jangka pendek (1-5 tahun) dan 16 usulan jangka panjang (6-15 tahun).
\end{abstract}

Kata Kunci-Industri furnitur, Industri 4.0, Metode Delphi, Rantai nilai, Rantai pasok.

\section{PENDAHULUAN}

$\mathrm{P}$ ERKEMBANGAN industri telah mencapai pada tahap revolusi industri 4.0. Revolusi industri 4.0 tidak hanya mengenai integrasi antara mesin dan sistem cerdas saja. Namun, pada revolusi industri 4.0 terjadi konektivitas manusia, mesin, dan data waktu yang secara nyata terjadi di mana saja [1], yang ditandai dengan integrasi teknologi dari Cyber-Physical-System di manufaktur dan proses logistik, serta penggunaan Internet of Thing (IoT) dan jasa di proses industrial [2]. Untuk menghadapi perkembangan industri ini, Presiden Joko Widodo telah meluncurkan sebuah program “Making Indonesia 4.0" pada awal April 2018.

Pada awal penerapan program menuju industri Indonesia 4.0, akan terdapat lima sektor industri utama yaitu industri makanan dan minuman, industri kimia, industri tekstil dan busana, industri elektonik serta industri otomotif dengan strategi rencana aksi yang telah disiapkan sesuai yang tertuang dalam program Making Indonesia 4.0. Revolusi industri 4.0 terlihat berpengaruh juga terhadap perindustrian yang lainnya salah satunya yaitu industri furnitur. Tidak kalah dengan lima sektor prioritas utama untuk implementasi
Making Indonesia 4.0, industri furnitur memiliki potensi sebagai salah satu komoditas yang dapat mendukung perkenomian Indonesia. Industri furnitur menjadi salah satu komoditi utama ekspor. Karakteristik yang unik, keterampilan berkualitas, keanekaragaman budaya, kombinasi bahan ramah lingkungan, serta inovasi yang unik mampu untuk mendorong ekspor produk furnitur [3]. Selain itu, berdasarkan catatan Kemenperin industri furnitur dapat menyerap banyak tenaga kerja dengan 140 ribu unit usaha yang bergerak di sektor industri furnitur dengan jumlah penyerapan tenaga kerja sebanyak 436 ribu orang dan nilai investasi mencapai Rp5,8 triliun pada tahun 2015 [4].

Namun, saat ini produk furnitur Indonesia masih tertinggal dengan negara lain seperti Malaysia, India, Thailand, dan Republik Rakyat Tiongkok yang menjadi eksportir terbesar furnitur di dunia saat ini [3]. Di samping itu di Indonesia telah masuk perusahaan furnitur asing yang memberikan banyak pilihan produk kepada konsumen seperti perusahaan IKEA, Informa dan ACE Hardware. Keadaan furnitur Indonesia saat ini masih mengalami kendala dengan ketersediaan suplai bahan baku, kebutuhan industri pendukung, pengembangan kreatif desain, pengadopsian teknologi, fasilitas infrastruktur, sumber daya manusia terampil, promosi dan pemasaran, penurunan suku bunga pinjaman di perbankan, tarif pajak, dan penegakan hukum [5].

Kini semakin banyak studi kasus dan telaah mengenai Industri 4.0. Beberapa contoh dilakukan pada perusahaan multinasional [6] dan banyak dilakukan pada industri manufaktur [7]-[10]. Dikatakan bahwa Industri 4.0 adalah fenomena yang akan datang, apakah itu diinginkan atau tidak. Seperti internet dengan ketidakpastian di tahun 1990an, dan kemudian muncul sebagai fenomena teknologi yang mendominasi dan vital. Oleh karena itu, semua produsen harus siap untuk merangkul revolusi industri potensial ini agar tetap kompetitif di pasar yang bergolak dan hiperkompetitif [11]. Telaah juga diamati bahwa perusahaan tidak berkompetisi secara individual tetapi juga dengan rantai pasokan mereka [12]. Lalu jika begitu bagaimana industri furnitur mampu untuk meningkatkan potensi industrinya dan menghadapi revolusi industri 4.0 ini, sebab hingga kini industri furnitur juga masih memiliki banyak kendala untuk bersaing. Oleh sebab itu perlu untuk dilakukan analisis nilai dari rantai pasok di industri furnitur. Hal ini diperlukan untuk peningkatan daya saing dan inovasi pada industri furnitur. Sehingga, tujuan penelitian ini adalah untuk memetakan rantai nilai dari rantai pasok industri furnitur Indonesia agar dapat bersaing di era industri 4.0. 


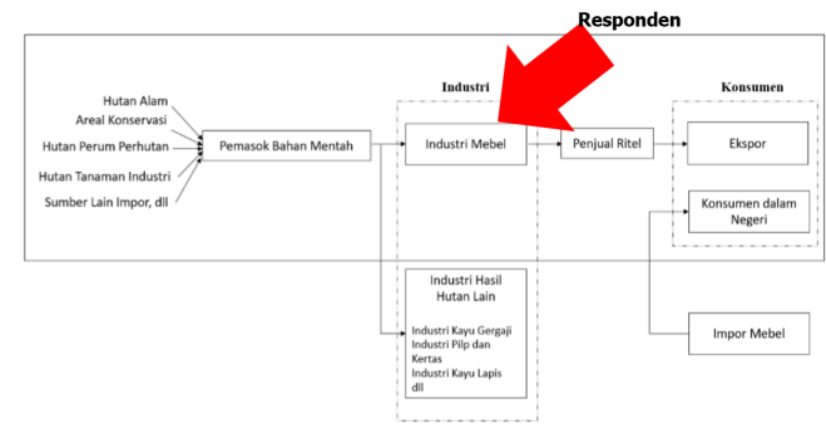

Gambar 1. Alur rantai pasok industri furniture

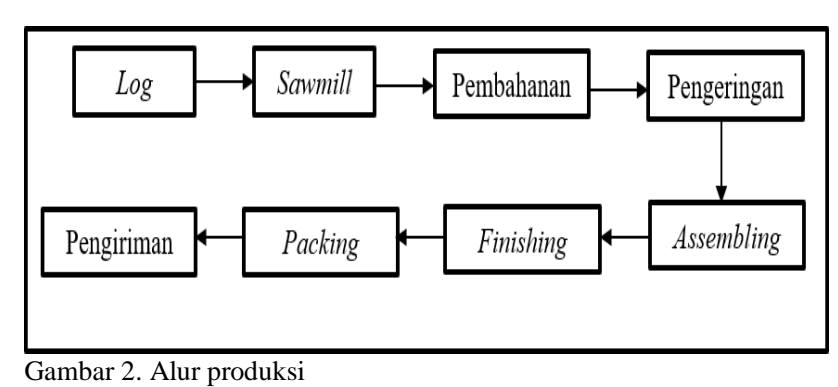

Gambar 2. Alur produksi

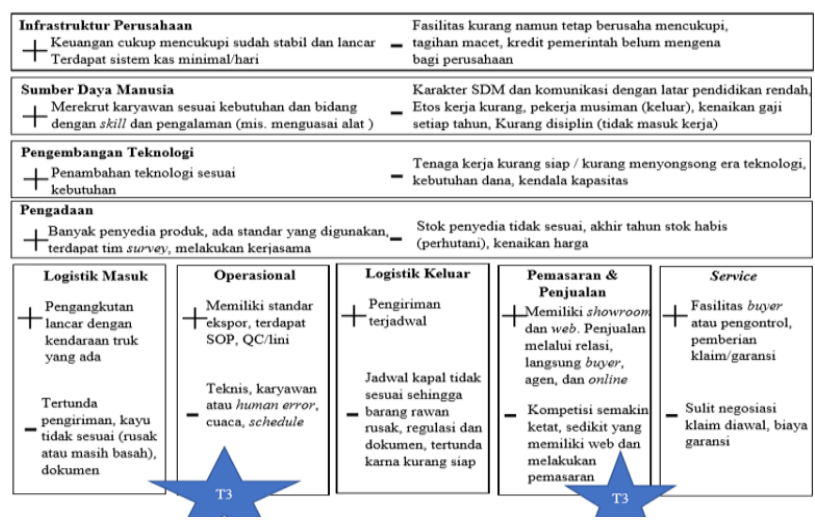

Gambar 3. Rantai Nilai Industri

\section{METODE PENELITIAN}

Metode yang digunakan pada penelitian ini yaitu metode kualitatif. Metode kualitatif digunakan untuk mencari pengertian yang mendalam tentang suatu gejala, fakta atau realita [13]. Desain penelitian dengan etnografi yaitu strategi dalam kualitatif yang merupakan studi terkait interaksi sosial, perilaku, dan persepsi yang terjadi di dalam tim, organisasi, dan komunitas melalui observasi dan wawancara [14]. Populasi pada penelitian ini yaitu perusahaan furnitur di Jepara, Jawa Tengah dan menggunakan perusahaan furnitur yang memproduksi furnitur kayu dan bergerak pada bidang ekspor sebagai sampel. Perusahaan furnitur akan diwakilkan oleh manajer atau yang bertanggungjawab dan mengerti dengan rantai pasok perusahaan. Pemilihan sampel yang digunakan yaitu snowball/chain sampling untuk membantu peneliti dalam memetakan rantai pasokan industri.

Pada proses pengumpulan data terhadap perusahaan furnitur Jepara, didapatkan 11 responden yang telah memberikan gambaran yang ada dan sudah tidak ada perubahan maupun penambahan yang terjadi. Sebelas responden terdiri dari 2 perusahaan yang memproduksi bahan setengah jadi, 6 perusahaan yang melakukan finishing,

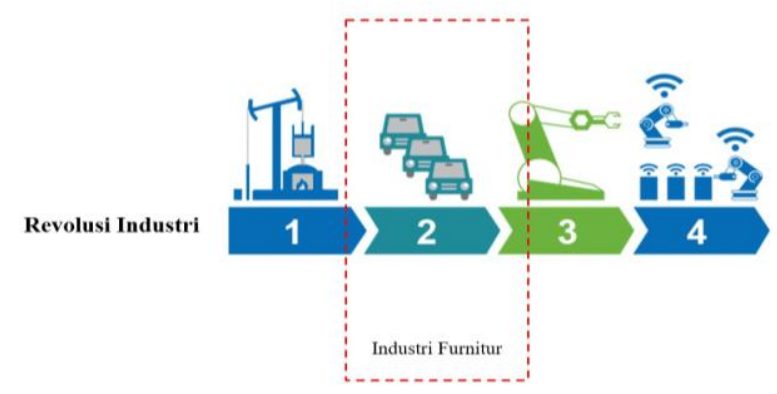

Gambar 4. Kondisi industri furnitur pada industri 4.0

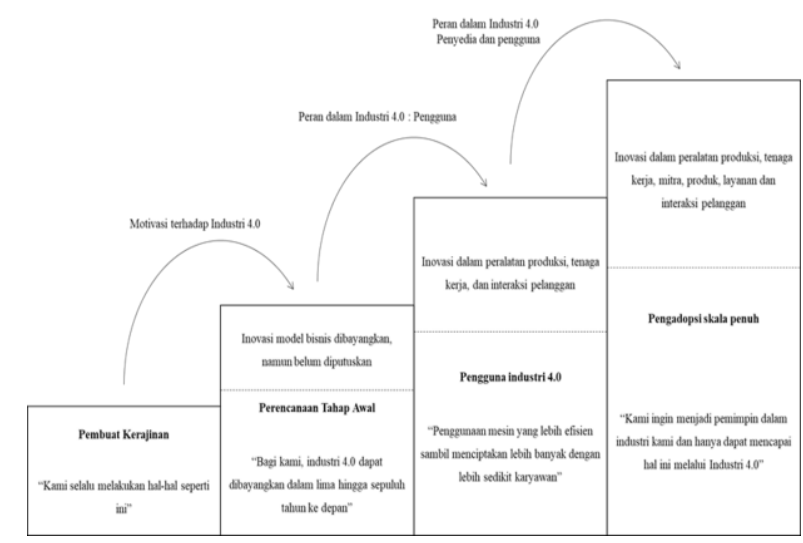

Gambar 5. Tahapan model dari industri 4.0

dan 3 perusahaan yang secara mandiri melakukan aktivitasnya dari awal pengolahan bahan baku hingga finishing dengan mengikuti chain pada perusahaan atau rekomendasi dari perusahaan.

Tahap analisis data dimulai dengan menggunakan value chain porter untuk melihat alur rantai pasok dan melakukan pemetaan rantai nilai industri furnitur dengan memeriksa semua kegiatan industri dari proses input ke output. Mengacu pada value chain porter yang membagi aktivitas utama dan sekunder. Dari analisis value chain porter ini akan ditentukan tingkatan penggunaan teknologi pada aktivitas yang dianggap utama menggunakan teknologi dan teknologi informasi dengan skala likert 1 (tradisional/sangat kurang) sampai 5 (sangat canggih/tinggi) jika dibandingkan dengan industri 4.0, sehingga akan tergambar keadaan penggunaan teknologi yang ada pada industri furnitur saat ini. Selanjutnya, berpacu pada penelitian Müller [15] akan dilakukan analisis keakraban industri furnitur dengan konsep industri 4.0 sesuai dengan persepsi mereka (industri furnitur) tentang fenomena industri 4.0 itu sebagai evolusi atau revolusioner, dan interpretasi mereka terhadap tantangan pelaksanaannya. Hingga tahap selanjutnya yaitu merancang strategi bagaimana industri akan berinovasi untuk industri 4.0 dengan menggunakan metode delphi. Responden pada perancangan strategi ini merupakan para expert pada rantai pasok dari perwakilan himpunan dan perusahaan furnitur yang mengetahui tentang industri 4.0.

\section{HASIL DAN DISKUSI}

\section{A. Rantai Pasok Industri Furnitur}

Jika dilihat pada rantai pasok industri furnitur (Gambar 1), responden termasuk ke dalam kelompok industri mebel. Responden untuk pemasok bahan mentah dan konsumen 
tidak didapatkan sebab terletak di luar wilayah Jepara dan sulit untuk dijangkau peneliti. Secara umum, dalam mengolah bahan baku hingga menjadi produk jadi melalui beberapa tahapan seperti pada Gambar 2. Proses produksi yang dimulai dengan pembelian bahan baku terutama kayu dalam bentuk gelondogan atau biasa disebut log. Setelah log datang, kemudian masuk pada proses sawmill yaitu pembelahan log menjadi bentuk papan sesuai ukuran yang dibutuhkan. Setelah menjadi papan masuk pada pembahanan, pembahanan merupakan proses pemotongan komponen sesuai dengan ukuran. Sehingga jika telah sesuai ukuran akan di masukkan pada proses pengeringan atau oven, rata-rata pada proses ini mencapai 2 minggu. Selanjutnya proses perakitan atau assembling dan sebelum proses akhir produk akan diamplas hingga mencapai proses finishing dan packing. Yang kemudian produk akan siap untuk dikirim. Sehingga pada proses produksi ini terbagi menjadi tiga perusahaan yaitu perusahaan yang mengolahan bahan baku mentah hingga menjadi bahan setengah jadi, perusahaan yang mengolah bahan baku untuk finishing, dan perusahaan yang secara mandiri mengolah bahan baku hingga menjadi produk jadi.

\section{B. Rantai Nilai Industri}

Tujuan penelitian ini adalah untuk memetakan rantai nilai dari rantai pasok industri furnitur Indonesia agar dapat bersaing di era industri 4.0. Sehingga dilakukan analisis rantai nilai yang dimiliki pada kelompok industri mebel ini yang terdapat beberapa bidang proses produksi perusahaan furnitur (produksi setengah jadi, finishing, dan secara mandiri memproduksi dari bahan baku hingga bahan jadi) untuk mendapatkan gambaran industri. Adapun rantai nilai industri pada Gambar 3.

Dari rantai nilai industri furnitur tersebut telihat bagaimana kondisi aktivitas industri yang terjadi saat ini dalam memberikan nilainya, sehingga terlihat juga beberapa kekurangan yang dimiliki sebagai berikut:

Aktivitas logistik masuk pada industri furnitur dalam proses pengiriman barang bakunya dari supplier yang umumnya memiliki jangkauan jauh sehingga menggunakan kendaraan truk untuk pengirimannya. Tidak adanya konektivitas digital seperti pada industri 4.0 sehingga kendala seperti tertunda pengiriman tak jarang terjadi. Jauhnya jangkauan supplier juga dapat membuat kemungkinan barang tidak sesuai ketika tiba pada perusahaan. Ketidaksesuaian ini seperti terjadinya kerusakan pada bahan baku dan perbedaan kondisi bahan itu sendiri.

Sebab industri furnitur ini berkegiatan ekspor, tentunya dalam penyampaian produknya kepada buyer perusahan memberikan tingkat kualitas yang tinggi dalam artian sesuai dengan standar ekspor. Untuk menjaga tingkat kualitas produknya tersebut kebanyakan perusahaan memiliki SOP yang diterapkan pada perusahaannya, selain itu pemberlakuan pengecekan atau quality control secara berkala pada setiap proses perpindahan barangnya. Dibandingkan dengan industri 4.0 kelompok mebel ini masih menggunakan tingkat penggunaan teknologi yang sedang. Semi mesin digunakan pada proses produksi kelompok mebel yang masih menggunakan tenaga manusia.

Hal inilah menjadikan kelompok industri mebel masih memiliki kendala teknis yang berhubungan dengan karyawan atau human error sering terjadi sebab pada prosesnya masih membutuhkan banyak tenaga manusia. Di perusahaan furnitur Jepara sendiri telah ada perusahaan yang menggunakan mesin $\mathrm{CNC}$ seperti mesin pada implementasi industri 4.0 yang dapat melakukan proses ukir dengan bantuan jaringan yang terintegrasi, namun ini masih jarang atau dapat dihitung jari yang menggunakannya. Sedangkan berdasarkan rantai nilai industri furnitur rata-rata masih menggunakan tingkat teknologi dan teknologi informasi yang sedang pada aktivitas operasional dan pemasaran serta penjualannya.

Pengiriman produk yang ekspor membuat perusahaan bergantung kepada pihak penyedia layanan kapal. Sehingga perencanaan penjadwalan pengiriman biasanya telah terjadwal. Ketergantungan terhadap pihak layanan kapal dengan pengiriman ke luar negeri ini biasanya terkendala pada proses penyiapan dokumen. Sebab regulasi setiap negara berubah membuat perusahaan harus teliti dalam menyiapkan dokumennya agar produk dapat diangkut oleh layanan kapal. Terlebih proses penyiapan dokumen masih dilakukan secara manual tidak digital. Tak hanya itu meskipun pengiriman telah terjadwal, dapat juga terjadi kemoloran pengiriman seperti pada saat peak season. Produk dapat saja tidak terangkut sehingga kontainer diletakkan pada gilirannya. Kontainer yang diletakkan pada area yang terbuka dapat menyebabkan suhu pada bagian dalam berubah sehingga barang akan rawan rusak jika terjadi hal seperti ini.

Perusahaan yang dapat melakukan kegiatan ekspor ini tidak terlepas dari proses pemasaran dan penjualan. Kebanyakan perusahaan ini menggunakan relasinya untuk dapat menjualkan produknya sehinngga langsung ke buyer. Sehingga sedikit yang memiliki web dan melakukan pemasaran yang berlebih. Sedangkan kompetisi saat ini semakin ketat, sehingga ada juga yang melakukan pemasaran dan penjualannya dengan melalui agen, memanfaatkan platform online, mengikuti event atau bahkan memiliki showroom. Namun, penjualan secara digitalisasi seperti pada industri 4.0 masih belum diterapkan pada kelompok industri mebel meskipun pada pemasarannya telah menggunakan platform online. Sehingga tingkat penggunaan teknologi dan teknologi informasi dibandingkan dengan industri 4.0 masih terbilang sedang.

Untuk menjaga royalitas buyer, perusahaan pada umumnya juga memberikan klaim atau garansi. Hal ini dikarenakan jarak pengiriman yang jauh sehingga perubahan kondisi mungkin saja terjadi. Selain itu terdapat perusahaan yang memberikan fasilitas lain bagi buyer nya seperti bagi pengontrol yang biasanya dikirimkan oleh buyer ke perusahaan untuk pengecekan produk yang akan dikirimkan tersebut. Ketergantungan kepada kondisi yang tidak pasti ini membuat perusahaan perlu melakukan negosiasi atau perjanjian diawal terkait dengan klaim atau garansi yang diberikan. Sehingga sulit negosiasi klaim diawal dapat terjadi, dan biaya garansi dapat mengurangi profit perusahaan.

Aktivitas dari proses logistik masuk hingga pemberian layanan tersebut tak luput didukung dengan aktivitas pengadaan, pengembangan teknologi, sumber daya manusia, 
dan infrastruktur perusahaan.

Adapun dalam aktivitas pengadaanya, industri furnitur tidak begitu kesulitan dalam mencari bahan bakunya atau suplai. Sebab di Indonesia sendiri penyedia produk atau pun bahan baku untuk industri furnitur masih mudah ditemukan sebab penyedia produk masih banyak. Ketersediaan pengadaan ini membuat perusahaan biasanya menyiapkan tim survey untuk melihat bahan baku yag cocok sesuai dengan standar yang digunakan dan menghindari stok penyedia yang tidak sesuai. Kerjasama dengan penyuplai juga sering diterapkan untuk memudahkan perusahaan dalam aktivitasnya. Beberapa perusahaan yang telah bekerjasama dengan perhutani mengeluhkan jika stok habis pada akhir tahun. Tidak adanya digitalisasi dan konektivitas seperti pada industri 4.0 membuat pengolahan kendala ini semakin lama. Sedangkan kenaikan harga juga dapat terjadi.

Penggunaan teknologi juga tentunya digunakan oleh industri furnitur untuk mendukung aktivitasnya terutama pada aktivitas operasional atau produksi yang memerlukan penggunaan banyak alat. Banyaknya alat yang digunakan pada proses produksi ini biasanya membuat penambahan teknologi sesuai kebutuhan sebab hal ini juga berhubungan dengan pendanaan dan kapasitas yang dimiliki. Selain itu juga dibutuhkan kemampuan manusia yang harus terus mampu untuk menyesuaikan perkembangan teknologinya.

Untuk sumber daya manusia, pada industri ini biasanya merekrut karyawannya yang sesuai kebutuhan dan bidang yang diimbangi dengan skill dan pengalaman yang dimiliki. Selain itu, kebanyakan kebutuhan karyawan ada pada bagian produksi sehingga skill penggunaan alat dipertimbangkan. Namun, skill penggunaan alat yang dipertimbangkan hanya pada mesin yang saat ini digunakan oleh industri kelompok mebel, sehingga tidak mempertimbangkan skill penggunaan teknologi terkini terlebih teknologi pada industri 4.0. Untuk pelatihan sendiri sedikit perusahan yang memberikan pelatihan terkait penggunaan alat tersebut. Latar belakang pendidikan pun tidak terlalu dipertimbangkan terutama untuk bagian produksi. Sehingga perusahaan biasanya menghadapi kendala terkait karakter dan komunikasi dengan karyawan yang memiliki latar pendidikan rendah. Selain itu kurangnya etos kerja dan kedisiplinan juga biasanya menjadi permasalahan yang dapat mempengaruhi produktivitas kerja. Sedangkan kenaikan gaji setiap tahunnya juga mengalami perubahan mengikuti UMK dan tidak diimbangi dengan tingkat penjualan. Berkaitan dengan keuangan pada umumnya keadaan keuangan perusahaan telah stabil dan lancar. Hal ini dikarenakan diimbangi dengan sebaikbaiknya perusahaan itu mengatur keuanggannya sebab tagihan macet dapat saja terjadi. Selain itu penerapan sistem kas minimal yang diberlakukan setiap harinya. Sehingga meskipun fasilitas kurang namun perusahaan tetap harus berusaha mencukupi. Meskipun kredit pemerintah ada namun hal ini masih dirasa belum mengena bagi perusahaan.

Dari rantai nilai dari tiap proses yang dilakukan oleh perusahaan furniture memperlihatkan pada Gambar 4.

Kondisi terkini dari industri furnitur jika dibandingkan dengan industri 4.0 berada pada tingkatan 2.0 dengan produksi massal dan penggunaan tenaga listrik. Hal ini juga dikarenakan aktivitas utama pada industri ini yang menggunakan teknologi dan teknologi informasi yaitu aktivitas operasional dan pemasaran dengan tingkatan yang masih sedang dibandingkan dengan industri 4.0. Selain itu, keadaan kelompok industri mebel pada industri furnitur saat ini yang berada pada tingkat industri 2.0 dengan proses produksi massal dan penggunaan semi mesin tenaga listrik. Sehingga sangat dibutuhkan pengembangan pada aktivitasaktivitas tersebut untuk menunjang perkembangan industri furnitur terlebih perkembangan industri telah mencapai tingkat keempat.

\section{Pandangan Terkait Industri 4.0}

Jika melihat industri 4.0 dengan membandingkan terhadap perusahaannya kesebelas responden memiliki tanggapan yang beragam terutama dalam penentuan jangka waktu di mana perusahaan furnitur akan mampu mengimplementasikan dari perkembangan industri 4.0. Namun rata-rata kesebelas responden ini menyatakan jika perusahaan dapat saja sesuai dengan industri 4.0 dengan jangka waktu implementasi 1-15 tahun.

Dari penentuan jangka waktu tersebut jika dikaitkan pada penelitian Müller [15] yang menampilkan empat kategori UKM dalam tipologinya (Gambar 5), yang dirancang untuk mendukung para praktisi dalam menganalisis posisi mereka sendiri terhadap Industri 4.0. Berdasarkan wawancara yang telah dilakukan terdapat delapan reponden yang telah dapat membayangkan akan industri 4.0 meskipun belum dapat memutuskannya, Sehingga dari hasil tersebut, industri furnitur ini menjadi bagian dalam rancangan tahap awal untuk industri 4.0. Seperti pada penelitian Müller [15], perusahaan telah melihat potensi diri mereka untuk industri 4.0. Meskipun terdapat ketidaksiapan dalam menerapkan teknologi baru, namun mereka mengharapkan akan implementasi industri 4.0. Sedangkan hanya tiga responden yang menyatakan tidak relevan. Golongan ini yang merupakan termasuk dalam pembuat kerajinan, yang telah nyaman pada keadaannya saat ini. Sehingga untuk mengikuti perkembangan industri terutama industri 4.0 motivasi sangat diperlukan pada golongan ini. Selain kurangnya motivasi, ada beberapa tantangan yang juga menjadi faktor kesulitan dalam melihat industri 4.0 di masa mendatang.

Sebab kondisi industri furnitur saat ini masih berada pada tingkat 2.0 terlebih ini gambaran dari industri yang telah bergerak dibidang ekspor. Sehingga untuk menuju industri 4.0 tersebut dibutuhkan tahapan strategi agar industri furnitur dapat bersaing pada era tersebut namun dengan memperhatikan faktor input yang sesuai dengan waktu yang tepat, kualitas yang tepat dan pada tempat yang benar.

\section{Rancangan Stategi}

Agar industri furnitur mampu untuk bersaing pada era industri 4.0, perancangan strategi dilakukan dengan menggunakan metode delphi. Pengumpulan usulan strategi didapatkan dari tiga ahli yang telah mengetahui mengenai industri 4.0 dengan pengalaman kerja dibidangnya. Para ahli terdiri dari manajer umum, export \& marketing manager, wakil ketua bidang promosi dan pemasaran organisasi. Metode delphi dilakukan dengan tiga iterasi. Pada putaran pertama kuesioner terbuka diberika kepada ketiga responden untuk usulan strategi aktivitas operasional dan aktivitas pemasaran dan penjualan. Dari penarikan opini putaran 
Tabel 1.

Prioritas strategi aktivitas operasional

\begin{tabular}{|c|c|c|}
\hline $\begin{array}{l}\text { Jangka } \\
\text { Waktu }\end{array}$ & Usulan Strategi & Pelaku implementasi \\
\hline \multirow{5}{*}{$\begin{array}{c}1-5 \\
\text { tahun }\end{array}$} & $\begin{array}{c}\text { Bantuan peremajaan mesin jangan } \\
\text { hanya kalangan tertentu }\end{array}$ & $\begin{array}{c}\text { Pemerintah } \\
\text { daerah/kota dan } \\
\text { Himpunan/asosiasi }\end{array}$ \\
\hline & Pemerataan bantuan/subsidi & $\begin{array}{c}\text { Pemerintah } \\
\text { daerah/kota dan }\end{array}$ \\
\hline & $\begin{array}{c}\text { Pemberian pelatihan khusus dan } \\
\text { pengembangan profesional } \\
\text { berkelanjutan }\end{array}$ & $\begin{array}{l}\text { Himpunan/asosiasi } \\
\text { Perusahaan }\end{array}$ \\
\hline & Efisiensi manajemen & Perusahaan \\
\hline & $\begin{array}{l}\text { Pengembangan desain dan } \\
\text { penggunaan teknologi terkini }\end{array}$ & Perusahaan \\
\hline \multirow{5}{*}{$\begin{array}{l}6-15 \\
\text { tahun }\end{array}$} & Penyederhanaan birokrasi & Perusahaan \\
\hline & $\begin{array}{l}\text { Peningkatan infrastruktur untuk } \\
\text { menunjang kapasitas produksi }\end{array}$ & Perusahaan \\
\hline & $\begin{array}{l}\text { Pengadopsian mesin tepat guna } \\
\text { (lokal) sesuai dengan nilai industry }\end{array}$ & $\begin{array}{c}\text { Pemerintah } \\
\text { daerah/kota dan } \\
\text { Perusahaan }\end{array}$ \\
\hline & Peningkatan R \& D & $\begin{array}{c}\text { Pemerintah } \\
\text { daerah/kota dan } \\
\text { perusahaan }\end{array}$ \\
\hline & $\begin{array}{l}\text { Peningkatan kualitas } \\
\text { manufacturing }\end{array}$ & Perusahaan \\
\hline
\end{tabular}

Tabel 2.

Prioritas strategi aktivitas pemasaran dan penjualan

\begin{tabular}{|c|c|c|}
\hline $\begin{array}{l}\text { Jangka } \\
\text { waktu }\end{array}$ & Usulan strategi & Pelaku implementasi \\
\hline \multirow{5}{*}{$\begin{array}{l}1-5 \\
\text { tahun }\end{array}$} & $\begin{array}{l}\text { Pengembangan produk baru } \\
\text { Pameran luar negeri }\end{array}$ & $\begin{array}{c}\text { Perusahaan } \\
\text { Pemerintah Pusat dan } \\
\text { Perusahaan }\end{array}$ \\
\hline & $\begin{array}{l}\text { Bantuan keikutsertaan pameran } \\
\text { luar negeri }\end{array}$ & Pemerintah Pusat \\
\hline & $\begin{array}{c}\text { Pendampingan } \\
\text { promosi/pameran luar negeri }\end{array}$ & $\begin{array}{c}\text { Pemerintah } \\
\text { daerah/kota dan } \\
\text { Himpunan/asosiasi }\end{array}$ \\
\hline & $\begin{array}{c}\text { Permudah untuk mendapatkan } \\
\text { bantuan promosi }\end{array}$ & Pemerintah pusat \\
\hline & $\begin{array}{l}\text { Dukungan pemerintah untuk } \\
\text { kemudahaan dan biaya regulasi }\end{array}$ & Pemerintah pusat \\
\hline \multirow{4}{*}{$\begin{array}{l}6-15 \\
\text { tahun }\end{array}$} & $\begin{array}{l}\text { Pengembangan infrastruktur } \\
\text { digital dari pemerintah untuk } \\
\text { mendukung proses bisnis }\end{array}$ & $\begin{array}{c}\text { Pemerintah pusat dan } \\
\text { daerah }\end{array}$ \\
\hline & $\begin{array}{c}\text { Pengembangan konsep layanan } \\
\text { desain di mana pelanggan tidak } \\
\text { hanya membeli produk tetapi } \\
\text { membeli layanan }\end{array}$ & Perusahaan \\
\hline & $\begin{array}{l}\text { Adanya stand/ruangan di kantor- } \\
\text { kantor konsultan luar negeri }\end{array}$ & Pemerintah pusat \\
\hline & $\begin{array}{l}\text { Penggunaan big data guna } \\
\text { customer relationship } \\
\text { management (CRM) }\end{array}$ & Perusahaan \\
\hline
\end{tabular}

pertama ini didapatkan 31 usulan dari para ahli dan 11 dari studi literatur yang terbagi dalam jangka waktu pendek dan panjang. Setelah didapatkan usulan strategi tersebut, peneliti merangkum usulan strategi yang didapatkan dan membentuk kuesioner yang terstruktur. Kuesioner disebarkan kembali ke setiap responden untuk divalidasi dengan setuju dan tidak setuju. Adapun persetujuan usulan strategi bernilai 1 dan ketidaksetujuan akan bernilai 0. Pada putaran kedua ini, terdapat beberapa tangapan terkait beberapa usulan dan juga ketidaksetujuan pada dua usulan strategi dari ahli. Sehingga pada tahap ini, hanya tersisa empat puluh usulan strategi untuk proses selanjutnya. Proses selanjutnya merupakan proses pembobotan usulan strategi kepada para ahli dengan skala liker 1-5. Di mana 1 bernilai sangat tidak penting hingga 5 bernilai sangat penting.

Pada putaran ketiga ini, empat puluh usulan strategi yang diproses telah konvergen dan tercapai konsensus. Hal ini terlihat dari jawaban atau penilaian dari ahli memiliki nilai standar deviasi yang kurang dari 1,5 dan interquartile range yang kurang dari 2,5. Selain itu para responden tidak melakukan perubahan terhadap penilaian yang diberikan Sehingga para ahli telah menganggap bahwa ke empat puluh usulan tersebut penting dan potensial untuk di kembangkan. Jika dilihat dari lima strategi dengan nilai rata-rata tertinggi, untuk implementasi strategi aktivitas operasional dapat dilihat pada Tabel 1.

Pada waktu jangka pendek, bantuan peremajaan mesin yang tidak hanya pada kalangan tertentu saja dan pemerataan bantuan/subsidi menjadi strategi prioritas utama untuk mengembangkan industri furnitur dalam menghadapi era industri 4.0. Hal ini cukup berkaitan dengan karakteristik dari industri 4.0 yaitu akselerasi melalui teknologi eksponensial. Penggunaan pencetakan 3D menjadi implementasi dari perkembangan industri ini. Meskipun belum mencapai pada tahap pengguna dari industri 4.0, peremajaan mesin menjadi sangat penting dalam mengikuti perkembangan dari industri dengan didorong peningkatan kualitas produk yang telah diterapkan agar dapat tetap bersaing pada era ini. Pemberian pelatihan khusus dan pengembangan profesional berkelanjutan juga dibutuhkan untuk menghasilkan sumber daya manusia yang kompeten yang dapat mengembakan inovasi dan peningkatan kemampuan penggunaan teknologi yang mengikuti perkembangan. Sehingga efisiensi manajemen untuk pengembangan proses ini sangat dibutuhkan. Hingga pada jangka panjang diharapkan terdapat peningkatan aktivitas R\&D dengan pangadopsian mesin yang tepat guna yang sesuai dengan nilai industri terutama nilai homemade yang tentunya tidak hanya meningkatkan nilai industri namun juga kualitas produksi. Peningkatan peralatan mesin ini tentunya perlu diimbangi dengan peningkatan infrastruktur perusahaan agar dapat menunjang kapasitas produksi. Sehingga dengan pengadopsian mesin di masa depan ini akan terjadi kebutuhan penyederhanaan birokrasi. Jika dilihat dari lima strategi dengan nilai rata-rata tertinggi, untuk implementasi strategi aktivitas pemasaran dan penjualan dapat dilihat pada Tabel 2.

Pada aktivitas pemasaran dan penjualan, strategi jangka pendek yang menjadi prioritas yaitu pengembangan produk baru dan pameran luar negeri yang didukung juga dengan bantuan promosi dan keikutsertaan pameran luar negeri. Sehingga dengan terjadinya program tersebut industri furnitur dapat melebarkan pangsa pasarnya dalam dunia internasional dengan produk baru yang memiliki nilai lebih. Sebab kegiatan industri furnitur mendukung kegiatan ekspor, di masa depan diharapkan akan dukungan pemerintah dalam kemudahaan regulasi dan kerendahan biaya sehingga akan membantu industri dalam proses ekspor. Selain itu, pengembangan infrastruktur digital dari pemerintah sangat 
dibutuhkan untuk mendukung proses bisnis terutama dalam aktivitas pemasaran dan penjualan di era industri 4.0 yang semua aktivitas perusahaan dapat mudah terintegrasi. Sehingga perusahaan tidak hanya menjual produk saja tetapi juga dapat menjual layanan. Penggunaan big data guna customer relationship management (CRM) juga dibutuhkan untuk menjaga loyalitas konsumen dan menjaring pembeli baru.

\section{SIMPULAN DAN SARAN}

Industri furnitur masih berada pada tingkat industri 2.0 dengan nilai yang dimiliki ukir dan proses produksi menggunakan banyak tenaga manusia dan teknologi semi mesin. Sehingga pengembangan perlu dilakukan pada aktivitas utama yang terjadi di industri furnitur yaitu aktivitas operasional dan aktivitas pemasaran serta penjualan yang memiliki tingkatan penggunaan teknologi dan teknologi informasi yang masih terbilang sedang jika dibandingkan dengan industri 4.0. Sebab pandangan industri furnitur terkait perkembangan industri 4.0 telah berada pada tahap perencanaan tahap awal. Industri telah dapat membayangkan implementasi industri 4.0 di masa yang akan datang dengan jangka waktu satu hingga lima belas tahun meskipun belum diputuskan. Adapun lima prioritas usulan strategi jangka pendek (1-5 tahun) yang dapat diaplikasikan pada aktivitas operasional industri furnitur menuju industri 4.0 yaitu pemerataan bantuan peremajaan mesin, pengembangan desain dan penggunaan teknologi terkini, efisiensi manajemen, pemberian pelatihan khusus dan pengembangan professional berkelanjutan, dan pemerataan bantuan atau subsidi. Adapun untuk jangka panjangnya (615 tahun) yaitu penyederhanaan birokrasi, peningkatan infrastruktur untuk menunjang kapasitas produksi, pengadopsian mesin tepat guna (lokal) sesuai dengan nilai industri, peningkatan R\&D, dan peningkatan kualitas manufakturing. Sedangkan, lima prioritas usulan strategi jangka pendek (1-5 tahun) yang dapat diaplikasikan pada aktivitas pemasaran dan penjualan untuk menuju industri 4.0 yaitu pengembangan produk baru, pameran luar negeri, bantuan keikutsertaan pameran luar negeri, pendampingan promosi atau pameran luar negeri, dan kemudahan untuk mendapatkan bantuan promosi. Adapun untuk jangka panjangnya (6-15 tahun) yaitu dukungan pemerintah untuk kemudahan dan biaya regulasi, pengembangan infrastruktur digital dari pemerintah untuk mendukung proses bisnis, pengembangan konsep layanan desain di mana pelanggan tidak hanya membeli produk tetapi membeli layanan, adanya stand atau ruangan di kantor-kantor konsultan luar negeri, dan penggunaan big data guna customer relationship management (CRM).
Meskipun begitu, pengimplementasian strategi tidak dapat dilakukan tanpa adanya sinergi baik antara pelaku industri furnitur, pemerintah, maupun akademisi. Dalam penelitian ini telah terbentuk roadmap strategi pengembangan industri furnitur agar dapat bersaing di era industri 4.0. Untuk penelitian selanjutnya diharapkan mampu untuk mengkaji atau menilai dari proses implementasi strategi yang ada. Selain itu pada penelitian selanjutnya juga diharapkan mampu untuk mengembangkan perbaikan-perbaikan langkah strategis sesuai dengan kriteria yang mempertimbangkan jenis lini bisnis yang dihasilkan (indoor maupun outdoor).

\section{DAFTAR PUSTAKA}

[1] K. Perindustrian, "Making Indonesia 4.0: Strategi RI Masuki Revolusi Industri Ke-4," www.Kemenperin.go.id, 08-Oct-2018.

[2] C. Bartodziej, The Concept Industry 4.0: An Empirical Analysis of Technologies and Applications in Production Logistics. Springer, 2016.

[3] Z. Salim and E. Munadi, "INFO KOMODITI Furnitur," Kemendag, 2017.

[4] K. Perindustrian, "Siaran Pers : Berorientasi Ekspor dan Padat Karya, IKM Furnitur dan Kerajinan Diprioritaskan," www.Kemenperin.go.id, 2018. [Online]. Available: http://www.kemenperin.go.id/artikel/18923/Berorientasi-Ekspor-danPadat-Karya,-IKM-Furnitur-dan-Kerajinan-Diprioritaskan.

[5] A. Sobur, "House of Indonesia Strategi meningkatkan," Allegra Tri Mitra, 2018.

[6] A. Telukdarie, E. Buhulaiga, S. Bag, S. Gupta, and Z. Luo, "Industry 4.0 implementation for multinationals," Process Saf. Environ. Prot., vol. 118, pp. 316-329, 2018.

[7] S. S. Kamble, A. Gunasekaran, and R. Sharma, "Analysis of the driving and dependence power of barriers to adopt industry 4.0 in Indian manufacturing industry," Comput. Ind., vol. 101, no. March, pp. 107-119, 2018.

[8] L. Li, "China's manufacturing locus in 2025: With a comparison of 'Made-in-China 2025' and 'Industry 4.0,'” Technol. Forecast. Soc. Change, no. February, pp. 0-1, 2017.

[9] G. Reischauer, "Industry 4.0 as policy-driven discourse to institutionalize innovation systems in manufacturing," Technol. Forecast. Soc. Change, vol. 132, no. December 2017, pp. 26-33, 2018.

[10] T. Stock and G. Seliger, "Opportunities of Sustainable Manufacturing in Industry 4.0," Procedia CIRP, vol. 40, no. Icc, pp. 536-541, 2016.

[11] M. Ghobaklhoo, "The future of manufacturing industry: a strategic roadmap," 2018.

[12] B. Nag, C. Han, and D. Yao, "Mapping supply chain strategy: an industry analysis," J. Manuf. Technol. Manag., vol. 25, no. 3, pp. 351-370, 2014.

[13] C. R. Semiawan, Metode Penelitian Kualitatif. Jakarta: Grasindo, 2010.

[14] S. Reeves, A. Kuper, and B. D. Hodges, "Qualitative research methodologies : ethnography," vol. 337, no. AUGUST, pp. 512-514, 2008.

[15] J. M. Müller, O. Buliga, and K. I. Voigt, "Fortune favors the prepared: How SMEs approach business model innovations in Industry 4.0," Technol. Forecast. Soc. Change, vol. 132, no. December 2017, pp. 2-17, 2018. 